\title{
Does Serum Vitamin D Concentration Modify the Association Between Arthritis and Cardiovascular Diseases in Both Sexes?
}

\section{Rachelle Saade}

Department of Social and Preventive Medicine, Faculty of Medicine, Laval University

\section{Danielle Laurin}

Centre d'excellence sur le vieillissement de Québec, Centre de recherche du CHU de Québec-Université Laval

Clermont E. Dionne ( $\square$ clermont.dionne@fmed.ulaval.ca )

Université Laval https://orcid.org/0000-0003-0806-5573

\section{Research article}

Keywords: Arthritis; cardiovascular diseases; sex; vitamin D; NHANES 2005-2006.

Posted Date: June 16th, 2020

DOI: https://doi.org/10.21203/rs.3.rs-35271/v1

License: (c) (i) This work is licensed under a Creative Commons Attribution 4.0 International License. Read Full License 


\section{Abstract}

Background: The scientific literature shows an association between inflammatory arthritis and cardiovascular diseases (CVD) with inflammation being a shared characteristic between the two types of diseases. Among patients with arthritis, it is possible that the protective factors against inflammation, such as vitamin $D$, are also protective factors against the development of CVD. This effect may be different according to sex.

Objective: To evaluate the impact of serum vitamin $D$ concentration on the association between arthritis and CVD separately among men and women (effect modification of vitamin D and sex).

Methods: Data came from a large representative sample of the US population: the National Health and Nutrition Examination Survey (NHANES) 2005-2006, which included 3406 adults aged between 20 and 69 years. Measurements of arthritis (primary independent variable) and CVD (dependent variable) were taken during face-to-face interviews, while the measurement of serum vitamin $D$ was carried out on blood samples. Multivariate logistic regression analyses were performed in which the combined modifying effect of vitamin $D(<20 \mathrm{ng} / \mathrm{ml} / \geq 20 \mathrm{ng} / \mathrm{ml})$ and sex was tested, and adjusted for several potentially confounding variables.

Results: Arthritis was statistically associated with CVD in both men and women, with $<20 \mathrm{ng} / \mathrm{ml}$ or $\geq 20$ $\mathrm{ng} / \mathrm{ml}$ serum vitamin $\mathrm{D}$. In men, the adjusted ratio of the odds ratios (ROR) comparing the association at $<20 \mathrm{ng} / \mathrm{ml}$ vitamin $\mathrm{D}$ concentration to the association at $\geq 20 \mathrm{ng} / \mathrm{ml}$ concentration was $0.8(95 \% \mathrm{Cl} 0.5$ to $1.5)$; in women, the adjusted ROR was 0.7 (95\% $\mathrm{Cl} 0.3$ to 1.5$)$.

Conclusions: In this large cross-sectional study, arthritis and CVD were statistically associated, but this association was not modified by sex nor vitamin D concentrations. Vitamin D supplementation is not recommended as part of the management of patients of both sexes suffering from inflammatory arthritis to prevent CVD.

\section{Background}

In the United States of America, about 52.5 million adults aged 18 years or older have clinically diagnosed arthritis. This disease is more prevalent among women and older adults [1]. Arthritis addresses a group of diseases of the musculoskeletal system affecting the joints and surrounding tissues $[1,2]$. If underdiagnosed or inadequately treated, patients may suffer from joint damage, functional limitations [3] and even increased mortality compared to the general population $[4,5]$.

An association between inflammatory arthritis and cardiovascular diseases (CVD) has been reported [69]. Chronic inflammation has an impact on atherosclerosis and insulin resistance, both potential cardiovascular risk factors [10]. Using NHANES dataset, we previously found a statistically significant association between arthritis and CVD [11]. It thus seemed reasonable to hypothesize that, among 
patients with arthritis, protective factors against inflammation could provide protection against the development of CVD. Vitamin D, an immune-modulator, could be such a protective factor $[10,12]$.

The assessment of 25(OH)D serum concentration is a relevant test diagnosing vitamin D deficiency [1315 ] because $25(\mathrm{OH}) \mathrm{D}$ is more stable and has a longer half-life. Season, aging, latitude, adiposity, physical activity, smoking and diet are factors that affect the associations between vitamin $D$ concentrations and health outcomes [16]. Vitamin D deficiency, defined as $25(\mathrm{OH}) \mathrm{D}$ serum concentration $<20 \mathrm{ng} / \mathrm{ml}[17-20]$ is considered a public health concern [21].

Vitamin D deficiency is common in patients with rheumatoid arthritis $[16,22]$ and is known to be associated with increased CVD risk [12, 22, 23]. It is not known, however, if this association is the same in men and women. In fact, we know that, except for children aged 1-5 years old, women have a higher prevalence of 25(OH)D deficiency than men [24], as well as a higher arthritis prevalence [1], and that sex differences do exist when it comes to inflammation [25,26] and CVD occurrence [27, 28]. However, a clear effect modification of sex on this association is not yet established. The objective of this study was to assess the impact, possibly differential between men and women, of serum 25(OH) D concentrations on the association between arthritis and CVD.

\section{Methods}

\section{Source of data}

National Health and Nutrition Examination Surveys (NHANES) are national cross-sectional surveys providing health and nutrition information on a representative sample of non-institutionalized U.S. residents of all ages that is generalizable to the entire U.S. population [29] . For the current study, we used data collected from NHANES 2005-2006 because it provided data relevant not only to arthritis and CVD, but also to serum measurement of $25(\mathrm{OH}) \mathrm{D}$. Participants signed written informed consent. Data were collected with health questionnaires, physical examination and blood tests [29]. The questionnaires were standardized and filled out during home interviews, while the physical examination and the blood collection were done in specifically equipped mobile centers travelling when needed to the participant's home [29].

\section{Sample selection}

Participants included were aged between 20 and 69 years. Exclusion criteria were mainly linked to the blood samples: 1) hemophilia, 2) received chemotherapy in the last 4 weeks, 3) presence of the following on two arms: rashes, gauze dressings, casts, edema, paralysis, open wounds, missing limbs, sclerotic veins, allergies to cleansing agents, burns or scar tissues. Besides the NHANES exclusion criteria, we excluded pregnant women and participants with incomplete physical exam or missing data related to vitamin D status. 
Figure 1 shows the detailed participants' selection: 10,348 individuals participated to NHANES 20052006, of whom 382 were pregnant women, 5323 participants were younger than 20 years, 882 were older than 70 years, $140(1.4 \%)$ had not completed the physical examination and $215(2.1 \%)$ had vitamin $D$ data missing. The final sample size available for the current study was 3406 ( $90.6 \%$ of those eligible).

\section{Main independent and dependent variables}

Participants reported their health conditions through the NHANES 2005-2006 "Medical Conditions Questionnaire". The main independent variable was the presence of arthritis; participants answered if they had been diagnosed as having arthritis, which included several diagnoses such as osteoarthritis, rheumatoid arthritis, spondylarthritis, psoriatic arthritis, etc. If the answer was "Yes" to the question: "Has a doctor or other health professional ever told you that you had arthritis?", then we considered them as having arthritis.

The dependent variable was the diagnosis of CVD; the questions were: "Has a doctor or other health professional ever told you that you had -congestive heart failure?"; "-coronary heart disease?"; "-angina pectoris?"; "-a heart attack?"; "-a stroke?" A positive answer to any of these questions was considered as a positive CVD diagnosis. This is the approach that was used in NHANES to estimate the prevalence of CVD [30].

\section{Other independent variables}

Several variables described participants' sociodemographic, lifestyle and physical characteristics (Table 1). Some were considered as potential confounders of the association between arthritis and CVD, based on biological plausibility and the literature $[8,16,31-34]$. Covariates included in analyses were age, sex, ethnicity, body mass index (BMI), total blood cholesterol concentration, 25(OH) D serum concentration and monthly dose of vitamin $D$ supplementation. In addition, we included the administration of glucocorticoids and anticonvulsants as potential confounders. In fact, some drugs (anti-convulsants, corticosteroids) adversely affect the vitamin D absorption [35,36]. BMI was calculated as weight in kilograms divided by the square of height in meters, and divided into 4 categories: underweight (BMl<18.5), normal weight (18.5<=BML $<24.9$ ), overweight $(24.9<=B M \mid<30)$, and obese $(B M I>=30)$. Total serum cholesterol $(\mathrm{mg} / \mathrm{dL})$ was considered as a continuous variable in analyses.

Details concerning the administration of glucocorticoids and anticonvulsants were extracted from NHANES 2005-2006 by matching two drug files ("Dietary Supplements" and "Prescription Medications") into a computer where an automatic match to a prescription drug database was performed [37].

Laboratory data provided measurements of serum concentrations of 25(OH)D for participants. The Diasorin 25-Hydroxyvitamin $\mathrm{D}(25(\mathrm{OH}) \mathrm{D})$ assay, an accurate kit measuring serum concentrations of 25(OH)D [38], was performed to first extract 25(OH)D metabolites from serum, and then separate and measure them [39]. NHANES uses different procedures to control the quality of the analyses performed 
by the laboratories [40]. Serum concentrations of 25(OH)D were dichotomized at $>20 \mathrm{ng} / \mathrm{ml}$ [17-20].

Finally, information on the participants' vitamin $D$ supplementation and its monthly dose were taken from several dietary data files available in the NHANES 2005-2006 database, that were merged.

\section{Statistical analyses}

SAS software (version 9.3) was used to perform statistical analyses. Sample weights were used to produce an unbiased national estimate of the civilian noninstitutionalized U.S. population[41]. Comparisons between arthritis and non-arthritis groups were conducted using chi-squared tests for categorical variables and Student's t test for continuous variables. To visualize bivariate associations of CVD with each of the independent variables, chi-squared tests were performed and the prevalence of CVD was calculated for each variable category. Multiple logistic regression was used to assess the association between arthritis and CVD. Age, total cholesterol and monthly dose of vitamin D supplementation were treated as continuous variables, while other variables were left categorical. Prevalence odds ratios (OR) with $95 \%$ confidence intervals $(95 \% \mathrm{Cl})$ were calculated. Age, sex, ethnicity, $\mathrm{BMI}$, total cholesterol, the administration of glucocorticoids and anticonvulsants, 25(OH)D serum concentration of vitamin $D(<20 \mathrm{ng} / \mathrm{ml} v s \geq 20 \mathrm{ng} / \mathrm{ml})$, and vitamin $D$ supplementation use were considered as potential confounding factors. Confounding was defined as a change in the OR $\geq 10 \%$ brought about by taking off one variable at a time compared to the full model. Effect modification was tested on a full model that included three double interaction terms (sex*arthritis, vitamin $D * a r t h r i t i s$ and sex*vitamin D) and a triple interaction term (arthritis*sex*vitamin D). This is because the main interest in this study were possible modifying effects of sex and vitamin D serum concentrations on the association between arthritis and CVD. To measure such effects, ratios of ORs (ROR) were calculated with their $95 \%$ confidence intervals; here, a ROR of 1.00 means no effect modification.

\section{Results}

\section{Descriptive analyses}

3761 adults were considered eligible, while 355 were excluded. No major differences existed between study participants and eligible non-participants except for the prevalence of arthritis. Actually, the nonparticipant group had an arthritis prevalence of $12.4 \%$ while the prevalence in the participants' group was $21.4 \%$. As for the prevalence of CVD, it was $7.1 \%$ in non-participants and $5.7 \%$ in participants.

Overall, 3406 participants comprised the study sample (Table 1), including 726 with a reported diagnosis of arthritis. Almost $90 \%$ of participants were aged between 20 and 60 years. Men and women were equally represented, with a majority of non-Hispanic Whites $(70.8 \%)$. Close to a third of participants (32.2\%) were overweight and $35.4 \%$ were obese. Deficient vitamin D concentrations ( $<20 \mathrm{ng} / \mathrm{ml}$ ) were found in $35.7 \%$ of participants, while a vitamin D supplementation was taken by $38.9 \%$.

Participants with arthritis were significantly older and more likely to be non-Hispanic Whites, female, obese and to have osteopenia than those without arthritis. They were also more likely to take 
glucocorticoids, anticonvulsants and higher doses of supplements of vitamin D. The prevalence of CVD was $14.1 \%$ among participants with arthritis and $3.4 \%$ among those without it $(p<0.0001)$. CVD were significantly more prevalent with increasing age, among underweight and obese participants, those with osteopenia and osteoporosis, those with lower concentrations of total cholesterol, those not taking glucocorticoids or anticonvulsants, and those taking vitamin D supplementation. There was a significant $(p=0.0015)$ bivariate association between serum vitamin D concentration and CVD: participants with $<20$ $\mathrm{ng} / \mathrm{ml}$ had a prevalence of CVD of $7.8 \%$ while those with $\geq 20 \mathrm{ng} / \mathrm{ml}$ had a prevalence of $4.5 \%$ (Table 1 ).

\section{Association of arthritis with CVD according to sex and serum vitamin D concentration}

Table 2 shows results of unadjusted and final multivariate models. In men, the unadjusted OR in participants with vitamin $D<20 \mathrm{ng} / \mathrm{ml}$ was similar to the $O R$ in participants with vitamin $D \geq 20 \mathrm{ng} / \mathrm{ml}$ (ROR: 1.1; 95\% Cl: 0.7-1.8), while there was a significant difference in women (ROR: 0.5; 95\% Cl: 0.3-1.0). The ROR comparing the association according to vitamin $D$ concentration and sex was also significant (ROR: 2.3; $95 \% \mathrm{Cl}: 1.2-4.5)$. These differences disappeared however in adjusted analyses: the $\mathrm{ROR}_{<20}$ $\mathrm{ng} / \mathrm{ml} / \geq 20 \mathrm{ng} / \mathrm{ml}$ among men was 0.8 (95\% Cl: 0.5-1.5), the ROR $<20 \mathrm{ng} / \mathrm{ml} />20 \mathrm{ng} / \mathrm{ml}$ among women was 0.7 (95\% Cl: 0.3-1.5), and the ROR combining both sexes was 1.1 (95\% Cl: 0.5-3.1); all adjusted ROR were not statistically different from 1.0 .

In men, the ROR $<20 \mathrm{ng} / \mathrm{ml} / \geq 20 \mathrm{ng} / \mathrm{ml}$ is obtained by dividing the OR of vitamin $\mathrm{D}<20 \mathrm{ng} / \mathrm{ml}$ (1.7) by the OR of vitamin $\mathrm{D} \geq 20 \mathrm{ng} / \mathrm{ml}$ (2.1). This ROR was 0.8 , which reflects that the odds of CVD in men with arthritis and $<20 \mathrm{ng} / \mathrm{ml}$ vitamin $D$ concentration is 0.8 times that of men with arthritis and $\geq 20 \mathrm{ng} / \mathrm{ml}$ vitamin D concentration. However, it was not statistically significant ( $p$-value: 0.50 ); we conclude that there was no significant difference between both ORs, and thus that no double interaction does exist in men between vitamin $\mathrm{D}$ concentration and arthritis.

In women, the ROR $<20 \mathrm{ng} / \mathrm{ml} />20 \mathrm{ng} / \mathrm{ml}$ is obtained by dividing the $\mathrm{OR}$ of vitamin $\mathrm{D}<20 \mathrm{ng} / \mathrm{ml}$ concentration (2.1) by the $O R$ of vitamin $D \geq 20 \mathrm{ng} / \mathrm{ml}$ concentration (3.1). This ROR is 0.7 which reflects that the odds of CVD in women with arthritis and $<20 \mathrm{ng} / \mathrm{ml}$ vitamin $D$ concentration is 0.7 times that of women with arthritis and $\geq 20 \mathrm{ng} / \mathrm{ml}$ of vitamin D. However, it was not statistically significant (p-value: 0.35 ); we conclude that there was no significant difference between both ORs, and thus that no double interaction does exist among women between vitamin $\mathrm{D}$ concentration and arthritis.

The ROR of 0.8 in men is not the same as that of 0.7 in women but this difference was not statistically significant. In fact, the combined ROR obtained by dividing 0.7 by 0.8 is 1.1 , the confidence interval includes the null value and its $p$-value is 0.68 . We thus concluded that no triple interaction does exist between arthritis, vitamin D concentration and sex.

\section{Discussion}

Using data from a nationwide survey, we found a statistically significant association between arthritis and CVD. However, this association was not different according to serum vitamin D concentrations nor 
sex in multivariate analyses.

The association between arthritis and CVD has been reported previously in several studies [7, 8, 31, 32] as well as the confounding effect of some factors such as age and sex, obesity, vitamin D consumption and its serum concentration, total cholesterol concentration, and the administration of anticonvulsants [7-9, 31].

Vitamin D serum concentration, involved in the inflammatory process [16, 42], could provide better understanding of the mechanism behind the association between arthritis and CVD. The concentrations of $25(\mathrm{OH}) \mathrm{D}$ have been shown to decline during health disorders characterized by inflammation, and are inversely correlated to inflammatory biomarkers such as C-reactive protein [16]. However, even if low 25(OH)D concentrations have been shown to be associated with several diseases such as arthritis and CVD, firm conclusions on vitamin D association with health disorders cannot be drawn because these associations were based on observational studies [34].

Our study was conducted on a large sample, representative of the U.S. population that provided high statistical power. The availability of serum vitamin D measures was a particularly interesting feature, providing more valid information than the usual dietary recalls.

There are some limitations that need to be discussed. The first one relates to the design of our study. Being cross-sectional, no causal relationship could be confirmed between arthritis and CVD. Another limitation is linked to the fact that 355 eligible subjects were eliminated from the study sample because of missing data related to physical examination and vitamin D status. According to NHANES, missing values are randomly distributed; however, the difference in the prevalence of arthritis between the study participants and the non-participants could reflect that arthritic subjects were more involved in the survey and blood collection than non-arthritic ones. To create an important selection bias, differences between both groups should be related not only to the exposure but also to the outcome. After comparing CVD prevalence between both groups, we did not notice a considerable difference, which brings us to conclude that the risk of selection bias is not high.

Both the dependent and the primary independent variables were reported pointing to possible misclassification. The fact of measuring simultaneously the exposure and outcome with reported measures may introduce a common method bias, generating an overestimation of the association between arthritis and CVD. Another source of non-differential misclassification exists: NHANES data provide a global measure for the arthritis disease; the term "arthritis" was not specific and included osteoarthrirtis, rheumatoid arthritis, spondylarthritis, psoriatic arthritis, etc. Inflammatory arthritis was not clearly defined nor measured. The disease was considered in general, and participants with inflammatory arthritis were not separated from those with non-inflammatory conditions.

As for confounding, we have identified several potential confounders in the literature $[8,16,31,32,34,43]$, though we were not able to fully control for all of them. The presence of osteoporosis [44] and alcohol consumption [5] were potential confounders, but we were not able to include these variables in our 
models because of the important number of missing values. In addition, HIV medications affect the vitamin $D$ metabolism and blood absorption $[35,45]$ and should have been considered as potential confounders for our analysis; however, these data were private in NHANES. Since HIV prevalence in the adults and adolescents US population was only $0.45 \%$ at the end of 2006 [46], we assume that this would not have caused big changes in our final estimates. Last, we were not able to get detailed data concerning the vitamin $D$ daily consumption, and data related to the participant's daily sunlight exposure was not available, so we could not include those variables as potential confounders.

In order to prevent statistical overadjustment, we removed some variables (administration of vitamin D and its monthly dose) from the regression models, to test the changes on the estimates and their precision. No major changes were noticed; the associations remained almost the same, so we kept them in our model, and we can confirm that our results were not affected by major overadjustment.

Multicollinearity between variables was tested before performing the regressions, and all correlation coefficients were neither larger than 0.9 nor smaller than -0.9 ; we thus conclude that multicollinearity was not important in our models.

From a clinical perspective, the CVD risk among arthritic patients should be taken more seriously and better CVD preventive interventions should be undertaken. However, since we have not found any effect modification by sex and vitamin D on the association between arthritis and CVD, we cannot conclude to the usefulness of vitamin $D$ administration as part of the management for patients suffering from inflammatory arthritis to prevent CVD. This is in-line with some meta-analyses that have confirmed a lack of association between vitamin $D$ deficiency and several diseases $[16,34]$ and there are no universal recommendations related to the daily intake of vitamin D supplementation [34]. It is difficult to conclude concerning the vitamin D supplementation effect because vitamin D absorption differs among people, and optimal levels of vitamin D concentrations are not the same for all outcomes [34].

The study of a shared cause for inflammatory arthritis and CVD should continue with prospective designs and more specific measures of both arthritis and CVD. Furthermore, information on exposure to sunlight would contribute to enhance the internal validity of results.

\section{Conclusions}

The association between arthritis and CVD is not modified by serum vitamin D concentrations nor sex. Prospective studies with more specific definitions of inflammatory arthritis and CVD are needed to shed more light on modifiable common risk factors of arthritis and CVD.

\section{List Of Abbreviations}

NHANES: National Health and Nutrition Examination Survey

CVD: Cardiovascular diseases 
25(OH)D: 25-Hydroxy Vitamin D

BMI: Body Mass Index

HIV: Human Immunodeficiency Viruses

ROR: Ratio of OR

SD: Standard Deviation

OR: Odds Ratio

\section{Declarations}

\section{Ethics approval}

The ethics committee of the Laval University (CERUL: https://www.cerul.ulaval.ca) validated that this type of research does not need ethical approval since it is based exclusively on secondary use of anonymous data, and information used is legally available to the public and adequately protected by the law.

\section{Consent to participate}

All participants provided written informed consent before participating to NHANES 2005-2006.

\section{Consent to publication}

Not applicable.

\section{Availability of data and materials}

The datasets supporting the conclusions of this article are available in the NHANES 2005-2006 website (http://wwwn.cdc.gov/nchs/nhanes/search/nhanes05_06.aspx

\section{Funding}

Not applicable.

\section{Competing interests}

The authors declare that they have no competing interests.

\section{Authors' contributions}

Rachelle Saade participated in conception and design, acquisition of data, analysis, interpretation, and drafting the manuscript. Clermont E. Dionne participated in conception and design, interpretation, and 
critical revision of the manuscript. Danielle Laurin participated in interpretation and critical revision of the manuscript. All authors read and approved the final manuscript.

\section{References}

1. Centers for Disease Control and Prevention. Arthritis 2019. Available from: https://www.cdc.gov/arthritis/basics/index.html

2. Arthritis Society. About arthritis. 2019. Available from: http://www.arthritis.ca/aboutarthritis.

3. Mease P, Garg A, Gladman D, Helliwell P. Development of simple clinical criteria for the definition of inflammatory arthritis, enthesitis, dactylitis, and spondylitis: a report from the GRAPPA 2012 annual meeting. J Rheumato/ 2013;40(8):1442-5.

4. Davenport G. Rheumatology and musculoskeletal medicine. Br J Gen Pract 2004;54(503):457-64.

5. Lahiri M. Using lifestyle factors to identify individuals at higher risk of inflammatory polyarthritis (results from the European Prospective Investigation of Cancer-Norfolk and the Norfolk Arthritis Register-the EPIC-2-NOAR Study). Ann Rheum Dis 2014;73:219-26.

6. Dessein PH. Vitamin D replacement therapy: a promising adjunct in cardiovascular risk management among patients with rheumatoid arthritis? J Rheumatol 2013;40(9):1463-5.

7. Hollan I, Meroni PL, Ahearn JM, Cohen Tervaert JW, Curran S, Goodyear CS, et al. Cardiovascular disease in autoimmune rheumatic diseases. Autoimmun Rev 2013;12(10):1004-15.

8. Soubrier M, Barber Chamoux N, Tatar Z, Couderc M, Dubost JJ, Mathieu S. Cardiovascular risk in rheumatoid arthritis. Joint Bone Spine 2014;81(4):298-302.

9. Meek IL, Picavet HS, Vonkeman HE, Verschuren WM, van de Laar MA. Increased cardiovascular risk factors in different rheumatic diseases compared with the general population. Rheumatology (Oxford) 2013;52(1):210-6.

10. Goshayeshi L, Saber H, Sahebari M, Rezaieyazdi Z, Rafatpanah H, Esmaily H, et al. Association between metabolic syndrome, BMl, and serum vitamin D concentrations in rheumatoid arthritis. Clin Rheumatol 2012;31(8):1197-203.

11. Saade R. Effets de la vitamine $D$ et du sexe sur l'association entre l'arthrite et les maladies cardiovasculaires Quebec,Canada: Laval University; 2016.

12. Baker JF, Mehta NN, Baker DG, Toedter G, Shults J, Von Feldt JM, et al. Vitamin D, metabolic dyslipidemia, and metabolic syndrome in rheumatoid arthritis. Am J Med 2012;125(10):1036.e9-e15.

13. Bhan I, Tamez H, Thadhani R. Impact of new vitamin D data on future studies and treatment. Curr Opin Nephrol Hypertens 2013;22(4):377-82.

14. Abrahamsen B, Harvey NC. The role of vitamin $D$ supplementation in patients with rheumatic diseases. Nat Rev Rheumatol 2013;9(7):411-22.

15. Greene-Finestone LS, Berger C, De Groh M, Hanley DA, Hidiroglou N, Sarafin K, et al. 25Hydroxyvitamin D in Canadian adults: biological, environmental, and behavioral correlates. Osteoporos Int 2011;22(5):1389-99. 
16. Autier P, Boniol M, Pizot C, Mullie P. Vitamin D status and ill health: a systematic review. The Lancet Diabetes \& Endocrinology 2014;2(1):76-89.

17. Wacker M, Holick MF. Vitamin D - effects on skeletal and extraskeletal health and the need for supplementation. Nutrients 2013;5(1):111-48.

18. Spedding S, Vanlint S, Morris H, Scragg R. Does vitamin D sufficiency equate to a single serum 25hydroxyvitamin $\mathrm{D}$ level or are different levels required for non-skeletal diseases? Nutrients 2013;5(12):5127-39.

19. Mertens PR, Muller R. Vitamin D and cardiovascular risk. Int Urol Nephrol 2010;42(1):165-71.

20. Cozzolino M, Ketteler M, Zehnder D. The vitamin D system: a crosstalk between the heart and kidney. Eur J Heart Fail 2010;12(10):1031-41.

21. Khadilkar VV, Khadilkar AV. Use of vitamin D in various disorders. Indian J Pediatr 2013;80(3):215-8.

22. Haque UJ, Bathon JM, Giles JT. Association of vitamin D with cardiometabolic risk factors in rheumatoid arthritis. Arthritis Care Res (Hoboken) 2012;64(10):1497-504.

23. Ranganathan P, Khalatbari S, Yalavarthi S, Marder W, Brook R, Kaplan MJ. Vitamin D deficiency, interleukin 17, and vascular function in rheumatoid arthritis. J Rheumatol 2013;40(9):1529-34.

24. Yetley E. Assessing the vitamin D status of the US population. Am J Clin Nutr 2008;8(2):5585-645.

25. Sokka T1, Toloza S, Cutolo M, Kautiainen H, Makinen H, Gogus F, et al. Women, men, and rheumatoid arthritis: analyses of disease activity, disease characteristics, and treatments in the QUEST-RA study. Arthritis Res Ther 2009;11(1):R7.

26. AhImen M, Svensson B, Albertsson K, Forslind K, Hafström I; BARFOT Study Group. Influence of gender on assessments of disease activity and function in early rheumatoid arthritis in relation to radiographic joint damage. Ann Rheum Dis 2010;69(1):230-3.

27. Mendis S, Puska P, Norrving B. Global Atlas on Cardiovascular Disease Prevention and Control. World Health Organization Geneva 2011.

28. Regitz-Zagrosek V, Lehmkuhl E, Weickert M. Gender differences in the metabolic syndrome and their role for cardiovascular disease. Clinical Research in Cardiology 2006;95(3):136-47.

29. Centers for Disease Control and Prevention. National health and examination survey overview, 20132014 201. Available from: http://www.cdc.gov/nchs/data/nhanes/nhanes_13_14/2013-

14_overview_brochure.pdf.

30. Kendrick J, Targher G, Smits G, Chonchol M. 25-Hydroxyvitamin D deficiency is independently associated with cardiovascular disease in the Third National Health and Nutrition Examination Survey. Atherosclerosis. 2009;205(1):255-60.

31. John H, Kitas G. Inflammatory arthritis as a novel risk factor for cardiovascular disease. Eur J Intern Med 2012;23(7):575-9.

32. Semb AG, Rollefstad S, van Riel P, Kitas GD, Matteson EL, Gabriel SE. Cardiovascular disease assessment in rheumatoid arthritis: a guide to translating knowledge of cardiovascular risk into clinical practice. Ann Rheum Dis 2014;73(7):1284-8. 
33. van Breukelen-van Der Stoep DF, Klop B, Van Zeben D, Hazes JM, Castro Cabezas M. Cardiovascular risk in rheumatoid arthritis: how to lower the risk? Atherosclerosis 2013;231(1):163-72.

34. Theodoratou E, Tzoulaki I, Zgaga L, loannidis JP. Vitamin D and multiple health outcomes: umbrella review of systematic reviews and meta-analyses of observational studies and randomised trials. BMJ 2014;348:g2035.

35. Holick MF. High Prevalence of Vitamin D Inadequacy and Implications for Health. Mayo Clin Proc,81(3):353-73.

36. Zhang R, Naughton DP. Vitamin D in health and disease: current perspectives. Nutr J 2010;9:65.

37. Prescription Medications (RXQ_RX_D ) [Internet]. 2008. Available from: http://wwwn.cdc.gov/Nchs/Nhanes/2005-2006/RXQ_RX_D.htm.

38. Carter GD. 25-Hydroxyvitamin D Assays:The Quest For Accuracy. Clinical Chemistry 2009;55(7):1300-2.

39. Vitamin D (VID_D) [Internet]. 2008. Available from: http://wwwn.cdc.gov/Nchs/Nhanes/20052006/VID_D.htm.

40. National Health and Nutrition Examination Survey. Laboratory procedures manual. 2017. Available from: https://wwwn.cdc.gov/nchs/data/nhanes/2017-

2018/manuals/2017_MEC_Laboratory_Procedures_Manual.pdf

41. Mirel LB, Mohadjer LK, Dohrmann SG. National Health and Nutrition Examination Survey: Estimation procedures, 2007-2010. Vital Health Stat 2. 2013 Aug;(159):1-17.

42. Hossein-nezhad A, Holick MF. Vitamin D for health: a global perspective. Mayo Clin Proc 2013;88(7):720-55.

43. Holick MF. The Vitamin D Epidemic and its Health Consequences. Journal of Nutrition 2005;135:2739S-48S.

44. Holick MF. Vitamin D: Important for Prevention of Osteoporosis, Cardiovascular Heart Disease, Type 1 Diabetes, Autoimmune Diseases, and Some Cancers. Southern Medical Journal 2005;9H(10):10247.

45. O'Neal JD. Vitamin D supplementation regimens for HIV-infected patients: a historical chart review. 2015. OHSU Digital Collections. https://doi.org/10.6083/M4R49PHF

46. Campsmith M, Rhodes P, Hall H, Green T. HIV Prevalence Estimates - United States, 2006. Div of HIV/AIDS Prevention, National Center for HIV/AIDS, Viral Hepatitis, STD, and TB Prevention, CDC 2008. Available from: https://www.cdc.gov/mmwr/preview/mmwrhtml/mm5739a2.htm

\section{Tables}

Table 1: Selected characteristics of subjects ${ }^{[1]}$ 


\begin{tabular}{|c|c|c|c|c|c|}
\hline & $\begin{array}{l}\text { Study } \\
\text { sample } \\
\text { n (\%) }\end{array}$ & $\begin{array}{l}\text { Without Arthritis } \\
\text { (\%) }\end{array}$ & $\begin{array}{l}\text { With Arthritis } \\
\\
\text { (\%) }\end{array}$ & value $^{\text {p- }}$ & $\begin{array}{c}\text { CVD } \\
\text { Prevalence } \\
\text { and p- } \\
\text { value }^{[3]}\end{array}$ \\
\hline (years) - n [missing] & $3406[0]$ & $2680[0]$ & $726[0]$ & $<0.0001$ & $<0.0001$ \\
\hline an \pm standard deviation) & $\begin{array}{c}(43.0 \pm \\
0.4)\end{array}$ & $(40.5 \pm 0.4)$ & $(52.1 \pm 0.6)$ & & \\
\hline $0-40$ years & $\begin{array}{l}1496 \\
(43.9)\end{array}$ & $1393(51.5)$ & $103(16.1)$ & & 1.2 \\
\hline $1-60$ years & $\begin{array}{l}1360 \\
(44.6)\end{array}$ & $1000(41.1)$ & $360(57.4)$ & & 6.6 \\
\hline 60 years & $\begin{array}{r}550 \\
(11.5)\end{array}$ & $287(7.4)$ & $263(26.6)$ & & 19.6 \\
\hline nicity- $\mathrm{n}$ [missing] & $3406[0]$ & $2680[0]$ & $726[0]$ & $<0.0001$ & 0.2996 \\
\hline Iexico-American & $743(8.4)$ & $654(9.8)$ & 89 (3.3) & & 4.1 \\
\hline ther Hispanic & $116(3.7)$ & $100(4.1)$ & $16(2.0)$ & & 3.6 \\
\hline 「on-Hispanics White & $\begin{array}{l}1563 \\
(70.8)\end{array}$ & $1167(68.7)$ & $396(78.7)$ & & 5.8 \\
\hline 「on-Hispanics Black & $\begin{array}{r}839 \\
(11.5)\end{array}$ & $647(11.8)$ & $192(10.3)$ & & 6.9 \\
\hline $\begin{array}{l}\text { ther race (including multi- } \\
\text { эcial) }\end{array}$ & $145(5.6)$ & $112(5.6)$ & $33(5.7)$ & & 5.4 \\
\hline
\end{tabular}




\begin{tabular}{|c|c|c|c|c|c|}
\hline & $\begin{array}{l}\text { Study } \\
\text { sample } \\
\text { n (\%) }\end{array}$ & $\begin{array}{l}\text { Without Arthritis } \\
\text { n } \\
\text { (\%) }\end{array}$ & $\begin{array}{l}\text { With Arthritis } \\
\\
\text { (\%) }\end{array}$ & $\begin{array}{c}\text { p- }^{[2]} \\
\text { value }^{[2]}\end{array}$ & $\begin{array}{c}\text { CVD } \\
\text { Prevalence } \\
\text { and p- } \\
\text { value }^{[3]}\end{array}$ \\
\hline :- $\mathbf{n}$ [missing] & $3406[0]$ & $2680[0]$ & $726[0]$ & $<0.0001$ & 0.5411 \\
\hline Iale & $\begin{array}{l}1745 \\
(50.1)\end{array}$ & $1437(52.4)$ & $308(41.5)$ & & 6.1 \\
\hline emale & $\begin{array}{r}1661 \\
(49.9)\end{array}$ & $1243(47.6)$ & $418(58.5)$ & & 5.3 \\
\hline $\begin{array}{l}\text { ly Mass Index (BMI) - n } \\
\text { ssing] }\end{array}$ & $3371[35]$ & $2655[25]$ & $716[10]$ & $<0.0001$ & $<0.0001$ \\
\hline $\begin{array}{l}\text { nderweight }(\mathrm{BMI}<18.5 \\
\left.\mathrm{g} / \mathrm{m}^{2}\right)\end{array}$ & $36(1.1)$ & $31(1.2)$ & $5(0.7)$ & & 11.1 \\
\hline $\begin{array}{l}\text { 「ormal weight (18.5-24.9 } \\
\left.\mathrm{g} / \mathrm{m}^{2}\right)\end{array}$ & $\begin{array}{r}956 \\
(31.3)\end{array}$ & $823(34.2)$ & $133(20.4)$ & & 2.4 \\
\hline Iverweight $\left(24.9-30 \mathrm{~kg} / \mathrm{m}^{2}\right)$ & $\begin{array}{l}1129 \\
(32.2)\end{array}$ & 935 (33.4) & $194(27.9)$ & & 5.4 \\
\hline Ibese $\left(\mathrm{BMI}>30 \mathrm{~kg} / \mathrm{m}^{2}\right)$ & $\begin{array}{l}1250 \\
(35.4)\end{array}$ & 866 (31.1) & 384 (50.9) & & 8.5 \\
\hline $\begin{array}{l}\text { noral neck bone mineral } \\
\text { sity }^{[4]} \text { - n (\%) }\end{array}$ & $\begin{array}{l}2789 \\
(617)\end{array}$ & $2239(441)$ & $550(176)$ & $<0.0001$ & $<0.0001$ \\
\hline 「ormal & $\begin{array}{l}2104 \\
(73.1)\end{array}$ & 1745 (75.9) & 359 (61.9) & & 4.5 \\
\hline
\end{tabular}




\begin{tabular}{|c|c|c|c|c|c|}
\hline & $\begin{array}{l}\text { Study } \\
\text { sample } \\
\text { n (\%) }\end{array}$ & $\begin{array}{l}\text { Without Arthritis } \\
\qquad \text { n } \\
\text { (\%) }\end{array}$ & $\begin{array}{l}\text { With Arthritis } \\
\qquad \begin{array}{l}\text { n } \\
\text { (\%) }\end{array}\end{array}$ & $\begin{array}{c}\text { p- } \\
\text { value }^{[2]}\end{array}$ & $\begin{array}{c}\text { CVD } \\
\text { Prevalence } \\
\text { and p- } \\
\text { value }^{[3]}\end{array}$ \\
\hline 'steopenia & $\begin{array}{r}658 \\
(25.9)\end{array}$ & $477(23.2)$ & $181(36.5)$ & & 7.8 \\
\hline 'steoporosis & $27(1.0)$ & $17(0.8)$ & $10(1.6)$ & & 16.9 \\
\hline $\begin{array}{l}\text { ohol consumption }{ }^{[5]}-\mathbf{n} \\
\text { ssing] }\end{array}$ & $\begin{array}{l}3160 \\
{[246]}\end{array}$ & $2469[211]$ & $691[35]$ & 0.0088 & 0.0596 \\
\hline ight consumption & $\begin{array}{l}2353 \\
(71.4)\end{array}$ & $1807(70.2)$ & $546(76.0)$ & & 6.5 \\
\hline Ioderate consumption & $\begin{array}{r}491 \\
(16.8)\end{array}$ & $397(17.2)$ & $94(15.5)$ & & 3.9 \\
\hline ïgorous consumption & $\begin{array}{l}316 \\
(11.8)\end{array}$ & $265(12.7)$ & $51(8.6)$ & & 3.7 \\
\hline $\begin{array}{l}\text { al cholesterol (mg/dL) - } \mathbf{n} \\
\text { ssing] } \\
\text { an } \pm \text { standard deviation) }\end{array}$ & $\begin{array}{c}3396[10] \\
(199.1 \pm \\
1.0)\end{array}$ & $\begin{array}{c}2673[7] \\
(198.0 \pm 1.0)\end{array}$ & $\begin{array}{c}723[3] \\
(202.8 \pm 1.6)\end{array}$ & 0.0166 & 0.0205 \\
\hline $\begin{array}{l}\text { otal cholesterol } \\
\text { oncentration }<200 \mathrm{mg} / \mathrm{dL}\end{array}$ & $\begin{array}{l}1889 \\
(54.5)\end{array}$ & $1501(55.1)$ & $388(52.4)$ & & 6.6 \\
\hline $\begin{array}{l}\text { otal cholesterol } \\
\text { oncentration }>=200 \mathrm{mg} / \mathrm{dL}\end{array}$ & $\begin{array}{l}1507 \\
(45.5)\end{array}$ & $1172(44.9)$ & $335(47.6)$ & & 4.4 \\
\hline
\end{tabular}




\begin{tabular}{|c|c|c|c|c|c|}
\hline & $\begin{array}{l}\text { Study } \\
\text { sample } \\
\text { n (\%) }\end{array}$ & $\begin{array}{l}\text { Without Arthritis } \\
\text { n } \\
\text { (\%) }\end{array}$ & $\begin{array}{l}\text { With Arthritis } \\
\\
\text { (\%) }\end{array}$ & $\begin{array}{c}\text { p- } \\
\text { value }\end{array}$ & $\begin{array}{c}\text { CVD } \\
\text { Prevalence } \\
\text { and p- } \\
\text { value }^{[3]}\end{array}$ \\
\hline $\begin{array}{l}\text { cocorticoids intake }-\mathrm{n} \\
\text { ssing] }\end{array}$ & $3378[28]$ & $2660[20]$ & $718[8]$ & $<0.0001$ & $<0.0001$ \\
\hline es & $49(1.4)$ & $25(0.9)$ & $24(3.4)$ & & 5.4 \\
\hline 「о & $\begin{array}{l}3329 \\
(98.6)\end{array}$ & $2635(99.1)$ & $694(96.6)$ & & 21.1 \\
\hline iconvulsants intake- $\mathrm{n}(\%)$ & $3378[28]$ & 2660 [20] & 718 [8] & $<0.0001$ & $<0.0001$ \\
\hline es & $140(4.3)$ & $69(2.7)$ & $71(10.1)$ & & 5.1 \\
\hline 「о & $\begin{array}{l}3238 \\
(95.7)\end{array}$ & 2591 (97.3) & 647 (89.9) & & 16.7 \\
\hline imin D supplementation- $\mathrm{n}$ & 3404 [2] & 2678 [2] & $726[0]$ & 0.2388 & 0.0181 \\
\hline es & $\begin{array}{l}1129 \\
(38.9)\end{array}$ & $866(38.4)$ & $263(41.0)$ & & 6.3 \\
\hline 「о & $\begin{array}{l}2275 \\
(61.1)\end{array}$ & $1812(61.6)$ & $463(59.0)$ & & 4.7 \\
\hline $\begin{array}{l}\text { nthly dose of vitamin D } \\
\text { plementation (IU) }{ }^{[6]}-\mathbf{n} \\
\text { ssing] }\end{array}$ & $\begin{array}{c}3390[16] \\
(4049.0 \pm \\
265.3)\end{array}$ & $\begin{array}{c}2667[13] \\
(3794.2 \pm 238.0)\end{array}$ & $\begin{array}{c}723[3] \\
(4987.1 \pm 731.4)\end{array}$ & 0.12 & 0.2580 \\
\hline :an \pm standard deviation) & & & & & \\
\hline
\end{tabular}




\begin{tabular}{|c|c|c|c|c|c|}
\hline & $\begin{array}{l}\text { Study } \\
\text { sample } \\
\text { n (\%) }\end{array}$ & $\begin{array}{l}\text { Without Arthritis } \\
\\
\text { (\%) }\end{array}$ & $\begin{array}{l}\text { With Arthritis } \\
\\
\\
\text { (\%) }\end{array}$ & value $^{\text {p- }}$ & $\begin{array}{c}\text { CVD } \\
\text { Prevalence } \\
\text { and p- } \\
\text { value }^{[3]}\end{array}$ \\
\hline 'ose $<12000$ IU & $\begin{array}{l}2888 \\
(82.2)\end{array}$ & 2304 (83.5) & $584(77.7)$ & & 5.5 \\
\hline ose $>=12000 \mathrm{IU}$ & $\begin{array}{r}495 \\
(17.8)\end{array}$ & 363 (16.5) & $139(22.3)$ & & 6.4 \\
\hline $\begin{array}{l}\text { Imin D serum concentration- } \\
\text { \%) }\end{array}$ & 3406 [0] & 2680 [0] & 726 [0] & 0.1146 & 0.0015 \\
\hline $20 \mathrm{ng} / \mathrm{mL}$ & $\begin{array}{l}1600 \\
(35.7)\end{array}$ & $1251(35.0)$ & $349(38.4)$ & & 7.8 \\
\hline$=20 \mathrm{ng} / \mathrm{mL}$ & $\begin{array}{l}1806 \\
(64.3)\end{array}$ & $1429(65.0)$ & $377(61.6)$ & & 4.5 \\
\hline diovascular diseases ${ }^{[7]}$ - n & 3406 [0] & 2680 [0] & $726[0]$ & $<0.0001$ & $\mathrm{NA}^{[8]}$ \\
\hline es & $241(5.7)$ & $114(3.4)$ & $127(14.1)$ & & NA \\
\hline 「о & $\begin{array}{l}3165 \\
(94.3)\end{array}$ & 2566 (96.6) & 599 (85.9) & & NA \\
\hline
\end{tabular}

${ }^{[1]}$ All values are weighted

[2] Statistical significance level: 0.05 for the comparison between both groups (arthritis versus non-arthritis); $\mathrm{chi}^{2}$ test for categorical variables and Student's $t$ test for continuous variables.

[3] Prevalence of cardiovascular diseases with the $\mathrm{p}$ value of a chi square test that highlights the bivariate association of cardiovascular diseases with each of the participant characteristics. 
${ }^{[4]}$ Normal when for men the femoral neck bone mineral density is $>0.79 \mathrm{gm} / \mathrm{cm}^{2}$, and for women $>0.74 \mathrm{gm} / \mathrm{cm}{ }^{2}$ Osteopenia when for men the femoral neck bone mineral density is between 0,59 and $0.79 \mathrm{gm} / \mathrm{cm}^{2}$, and for women between 0.56 and $0.74 \mathrm{gm} / \mathrm{cm}^{2}$

Osteoporosis when for men the femoral neck bone mineral density is $<0.59 \mathrm{gm} / \mathrm{cm}^{2}$ and for women $<0.56$ $\mathrm{gm} / \mathrm{cm}^{2}$

[5]

Light alcohol consumption: $\mathrm{M}:<=3$ drinks per week- $\mathrm{F}$ : $<=3$ drinks per week

Moderate alcohol consumption: M: between 3 and 14 drinks per week- F: between 3 and 7 drinks per week Vigorous alcohol consumption: M: more than 14 drinks per week- F: more than 7 drinks per week

[6]

IU: International Units

[7] Includes congestive heart failure, coronary heart disease, angina/angina pectoris, heart attack, and stroke [8]

NA: Not Applicable for this table

Table 2- Results of bivariate and multivariate analyses on the association between arthritis and cardiovascular diseases by sex and vitamin D concentration $(n=3406){ }^{[1]}$ 


\begin{tabular}{|c|c|c|c|c|c|}
\hline \multicolumn{2}{|c|}{} & \multicolumn{2}{|c|}{ Women } & \multicolumn{2}{c|}{$\begin{array}{c}\text { Ratio of OR (Men vs } \\
\text { Women })\end{array}$} \\
\hline $\begin{array}{c}\text { OR or } \\
\text { ROR } \\
\begin{array}{c}(95 \% \mathrm{CI}) \\
{[3]}\end{array}\end{array}$ & $p$-value & $\begin{array}{c}\text { OR or ROR } \\
(95 \% \mathrm{CI})\end{array}$ & $p$ value & ROR (95\% CI) & $p$-value \\
& & & & \\
\hline
\end{tabular}

\section{UNADJUSTED}

\begin{tabular}{|l|c|c|c|c|c|c|}
\hline $\begin{array}{l}\text { Vitamin D }<20 \mathrm{ng} / \mathrm{ml} \\
\text { concentration }\end{array}$ & $\begin{array}{c}4.8(3.0- \\
7.7)\end{array}$ & $<0.0001$ & $3.6(2.0-6.6)$ & $<0.0001$ & - & - \\
\hline $\begin{array}{l}\text { Vitamin } \mathrm{D} \geq 20 \mathrm{ng} / \mathrm{ml} \\
\text { concentration }\end{array}$ & $\begin{array}{c}4.2(2.9- \\
6.2)\end{array}$ & $<0.0001$ & $7.3(3.0-17.4)$ & $<0.0001$ & - & - \\
\hline $\begin{array}{l}\text { Ratio of OR }(<20 \mathrm{ng} / \mathrm{ml} / \geq 20 \\
\mathrm{ng} / \mathrm{ml})[2]\end{array}$ & $\begin{array}{c}1.1(0.7- \\
1.8)\end{array}$ & 0.5817 & $0.5(0.3-1.0)$ & 0.0367 & $2.3(1.2-4.5)$ & 0.0161 \\
\hline
\end{tabular}

\section{ADJUSTED $^{[4]}$}

\begin{tabular}{|l|c|c|c|c|c|c|}
\hline $\begin{array}{l}\text { Vitamin D }<20 \mathrm{ng} / \mathrm{ml} \\
\text { concentration }\end{array}$ & $\begin{array}{c}1.7(1.0- \\
3.0)\end{array}$ & 0.0508 & $2.1(0.9-5.1)$ & 0.1074 & - & - \\
\hline $\begin{array}{l}\text { Vitamin D } \geq 20 \mathrm{ng} / \mathrm{ml} \\
\text { concentration }\end{array}$ & $\begin{array}{c}2.1(1.3- \\
3.4)\end{array}$ & 0.0017 & $3.1(1.1-9.0)$ & 0.0361 & - & - \\
\hline $\begin{array}{l}\text { Ratio of OR }(<20 \mathrm{ng} / \mathrm{ml} / \geq 20 \\
\mathrm{ng} / \mathrm{ml})\end{array}$ & $\begin{array}{c}0.8(0.5- \\
1.5)\end{array}$ & 0.5008 & $0.7(0.3-1.5)$ & 0.3457 & $1.1(0.5-3.1)$ & $0.679^{[6]}$ \\
\hline
\end{tabular}

[1] All values are weighted with the full sample 2-year interview weight and the full sample 2-year MEC exam weight

[2] Combined effect modification of vitamin D and sex; interaction term (arthritis*sex*vitamin D)

[3] OR (95\% CI): Odds Ratios with 95\% confidence interval; ROR (95\% CI): Ratio of OR with 95\% confidence interval 
[4]

Adjusted for age, supplementation of vitamin D and its monthly dose, body mass index, administration of anticonvulsants, total cholesterol concentration, and main effect of vitamin D serum concentration and sex [5]

Effect modification by vitamin D concentration; interaction term: (arthritis*vitamin D)

${ }^{[6]}$ P-value for combined effect-modification

\section{Figures}

\section{Participants Selection}

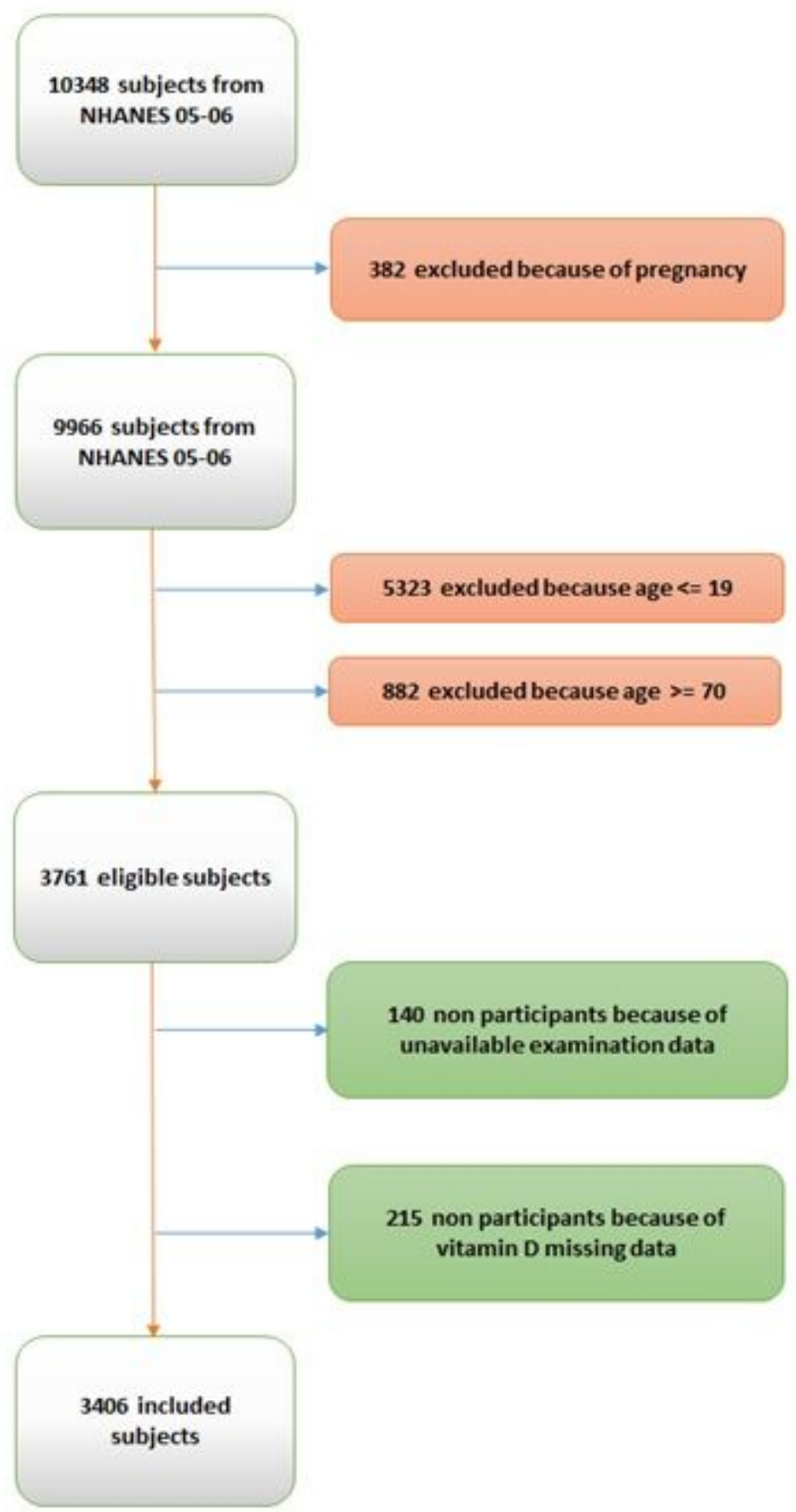


Figure 1

Participants' selection schematization 